\title{
Promoting Political Modernizations by Building Civic Cultures
}

\author{
Lin Qiu \\ Department of Humanities and Social Sciences, Henan Institute of Engineering, Zhengzhou, P.R. China 451191 \\ qiulin4159@163.com
}

\begin{abstract}
The cultivation of civic cultures is necessary for contemporary China to accelerate its development. The paper will explore the role of civic cultures played in political and cultural development to enhance political modernizations.
\end{abstract}

Index Terms - civic cultures; Political Modernization; building

\section{Introduction}

Civic cultures, or political cultures, are first proposed by American politician G. A. Almond. With political life and behavior culturally explored, people's attitudes to political system, include their mentality and evaluation of political consciousness and participation. Civic cultures are combined with political initiatives and positive attitudes, which guides and controls such actions. Chinese civic cultures are oriented by democracy, freedom and equality, characterized by civil consciousness, values, attitudes, feelings, morality, legislation and beliefs. The cultures are fused with different ideas, mentality, behavioral and social norms, which are specifically the core values of socialism. The cultures in China began in the 80 s of the $20^{\text {th }}$ century, and at present Chinese politics have developed more democratically and culturally. Thus, how to build up civic cultures has become the important subject to build democracy and cultures. Generally, such issues are studied as the background of civic cultures, Chinese civic cultures, the elements to limit the cultivation of civic cultures and the choice of paths to develop them. While some goals have been achieved in the study at home, the development of civic cultures still needs to be paid attention to. The paper will explore the role of civic cultures played in political and cultural development to enhance political modernizations.

\section{The Role of Civic Cultures Played in Political Modernization}

The former secretary of the United Nations said, "Political modernizations must commence with democracy, which is essentially not violent." [1] What the secretary said means cultivating civic cultures, or political cultures. The cultures are "pluralistic on the basis of communication and persuasion, combined with consistency and variety, one with gradual change."[2] They are essentially made up of constitutional and political ideas, participation awareness, rights and responsibility, which have established a kind of balanced political tendency, with participation, supervision, rights, controversy and criticism based on order, identity, law, supervision, and tolerance respectively. Citizens cultivated in civic cultures are commonly reasonable for their actions without violent tendency in political life, and their requirements of benefits are confined by law. Therefore, democracy and politics are compatible with civic cultures and significant for political modernizations.

\section{1) Civic Cultures as the Base of Political Modernizations}

Democracy and politics are the core of political modernizations either in social transition of history or the democratic process. American socialist A. Engels surveyed every corner of society with the result that modernization first means human modernization. He pointed out, "if every person has modern personality in psychology and behavior, and every administrator shows modernity in politics, economy and culture, the country is really modernized. Otherwise, fast and stable economy will be impossible. Even if taking off, it cannot endure long."[3] With democracy serving as the precondition of political modernization, the differences in democracy or citizens' political cultures are thought of as the standard for political modernization. Political activities are based on types of political cultures, political mentality and values. Thus, the systematic civilizations must be based on development of civic cultures.

\section{2) Civic Cultures as Booster of Political Modernization}

Hentinton thinks that the political cultures influence democracy. In history of democracy, all the democracy was connected with political cultures. Without political cultures, any democracy will have no firm ideological bases. The Enlightenment in 17-18centuries is epochal culturally and politically, as the bourgeoisie fought in response to the political revolution. It boosted the movement in Europe, as feudalism was turned over and civic cultures established. Also, democracy has been difficult to establish in some developing countries since World War II, since political cultures have not been established. Democracy depends on citizens' attitudes for politics. Therefore, civic cultures are made up of political beliefs, participation awareness, ideas of rights and responsibility.

When civic cultures are deeply rooted in national cultures, accepted by most citizens and fused into public activities and values, political modernizations can sustain. In other words, civic cultures reflect the basic principles of democracy and will boost up political modernization.

3) Civic Cultures as Stabilizer of Political Modernization

American scholar C. E. Burlake pointed out that modernizations mean the destruction of traditional society. It 
was proved in history that in the transition from the old to the new, both positive and negative mentalities exist and cause mental conflicts and must be avoided to help social develop.

In order to keep the stability of Chinese reformation and avoid the frustration 、 stagnation and retrogression experienced by some other developing countries in the process of political modernization, civic cultures must be established. Civic cultures are a kind of balance of political orientation, like the balance of political supervision and identity, rights and law, competition and consultation, criticism and tolerance. Balance between agreement and disagreement, rights and responsibility, emotion and reason are all the stabilizers of society. Civic cultures are liable to lead to political identity and public attitudes to the same social event and then an invisible regulation of concepts. Civic cultures are also a sort of spirits to control people's desire and behaviors.

\section{Enhance the Development of Civic Cultures to Further Political Modernizations}

Realization of political modernization not only needs to cognize and seek for democracy in theory but also fuse it into citizen's personality system and be transformed into civil intrinsic cognition, emotion, attitude and behavior habits. Thus, civic cultures must be cultivated to fit political modernizations.

\section{1) Strengthen the cultivation of citizen consciousness to promote the construction of civil culture}

In the construction of the civic culture, Awareness of freedom, equality and independence is to be boosted up. Firstly, establish political consciousness. Establishment of political awareness is to develop senses of responsibility, get rid of political indifference and excite their political enthusiasm. Secondly, strengthen the awareness of citizens' 'political participation. The intensity of participation in democratic politics fundamentally reflects the concern, understanding and behaviors of the "political people" about their social status and activities, so the sense of participation plays a driving and guiding role. Fourthly, develop citizens' legal awareness. As the guide of democracy and politics, legal consciousness is helpful for orderly participation in politics, reasonable and lawful requirement for their benefits and social stability. Lastly, develop citizens' senses of political tolerance. As the influence of feudal political culture, the irrational behavior is easy to go to extremes, such as docility and obedience, political apathy. The political fanaticism as a whole is due to the lack of tolerance and mutual understanding. In modern China, political tolerance is the important goal and precondition for politics and democracy. A stable society is necessary for China's political modernization, in which political tolerance plays a role

2) Strengthening the construction of the civic culture by broadening political communication channels

According to modern political theory, It is a good way of adjusting political psychology that expands and maintains the political communication channels. If the democratic demand of citizens can not be met by widening political communication channels, political modernization will be hindered. When citizens' political needs cannot be satisfied, their trust in government and enthusiasm about politics can be weakened. Political indifference influences policies, with government illinformed, subjective, monarchic and misleading. Also, political indifference will transform into disobedience, potential conflicts and resistance. In a word, reformation of political input and output systems in development of political communication, and adjustment of democratic mentality are important contents of civic cultures, which are helpful for China's political modernization

\section{3) Strengthening Education for Citizens by Developing Civic Cultures}

From the point of view of political science, any kind of political system is not solid and durable if it only stays in the system level. Only after the value orientation and the goal connotation of the political system are accepted by people, it can produce tremendous energy and promote the process of political modernization. So we must strengthen citizen education to adapt to the needs of political modernization. As to the educational goal, the correct political attitude and the concept of socialism must be established, and the citizen consciousness must be cultivated by the systematic education. As to the educational approaches, in addition to theoretical propaganda, we should focus on the beginning of the practice in order to guide the citizen's political participation and democratic practice. Without full growth of civic cultures, democracy cannot be truly implemented. It requires all citizens to develop the civic awareness of political modernization

\section{Conclusion}

Civic cultures are indispensable for political modernizations. For the realization of a national political modernization, not only the constitutional system needs to be designed, but also the democratic value will be fused into citizens' personalities and intrinsic cognitions, emotions and attitudes, which is significant in the political life. Thus, civic awareness and political communication must be enhanced to contribute to political modernizations.

\section{Reference}

[1] Jun Ning Liu: Democracy and Democratization . Beijing: The Commercial Press, 1999.

[2] G. A. Almond\& S.Webar: Civic Cultures . Taipei:Wunan Publishing House, 1996.

[3] Engels: Human Modernizations- Psychology, Ideas, Attitudes, Behaviors .Trans. by Lu Jun Yin. Chengdu: Sichuan People’s Press, 1985.

[4] Xiao Guang: Motivations of Modernization . Chengdu: Sichuan People's Press, 1988. 